のな

半 增 香

分大港

の経 は

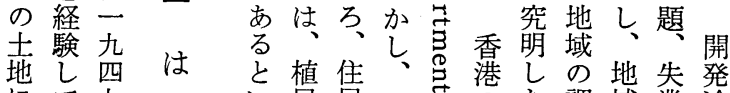

にて杂じ民良こたのた調域業途

き年し地参のでコも查の問占

一た以こ支加互あミの萡連題国

九 点来に と配と助る。で委带感交多

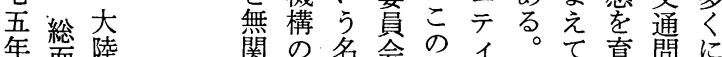

年面陸関の名会の和充問に

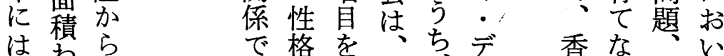

はわらで格を少古デ香な教

四ずの赫保真住べ港が教て

三英民萑

七、流

九 $\bigcirc$ 入

よ来计良を

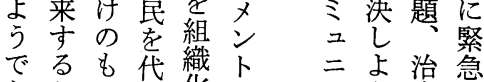

九公よ

あとの表化にテう安な

平 る

○方人

る思文等し主 1 と問 社

人キ口

の口圧

ひ 力

と東の

び京急

と 都 激

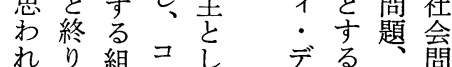
れり、組录して デる 社閴 この織之関 品が会と れたな迋メ都祉て をめつ令る ン市問解 䩦コて向整占に題決

○リあ加が革ミな在機、け医迫 九夕たと住よュいを関どる療ま

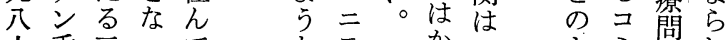

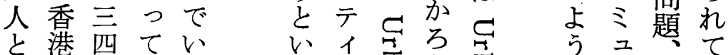
無巷四てい 界集万る。゙ 最しがーこ 娶て香九れ 過お港七は

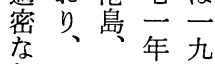
都そ九の五 市の龍七二 の人尓

ひ口新サの

と密九 ス 総 う度龍に人 よは荃れに つ平湾ば比 て方の都る いキ都総る る。市人 立 特た部の . にりメ八二 旺一下八倍 角七゙呆\%の う. 動デ导点质公る

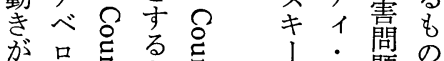

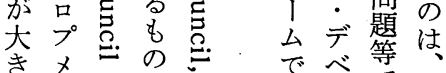
きメのがこで等 な卜民导行品急

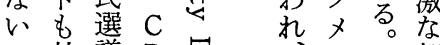

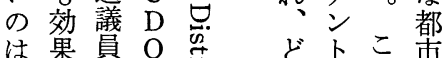
は果員 O 新あし組な計らに 界げろ、織○う画のよ のて・、等串なで課る 租い互るこ問あ題て 借な助互五題る。生 期、。委助气 委㤂こ住た 唯そ会賲々 から售住 香 港 
のる降題とに展め港のて以、庁貸し八的に人領地体は 自。経く降しは写、六経四口主にに 助政中対に心てのと済るそか従さ新 ○緯六しの林兵そ 府央态さていでし政このし来れ界年の八か八立陵の

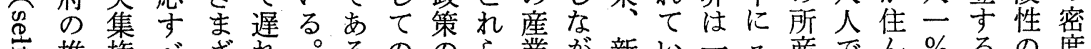
字推権べざれ。るののら業が新い一そ産でん％るの度

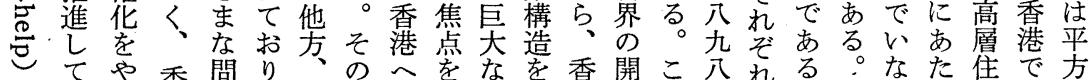

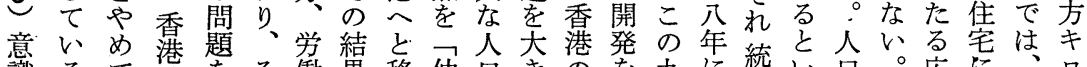
識るて政をそ衝果移仲口きのを九に統い口。広に、口

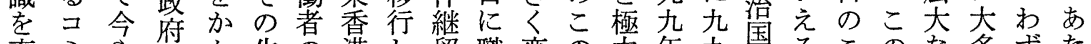
育ミや条か生の港し貿職変の力年九国るこのな多ずた 成二地部え活生で、易を換急押間年で。の新農数かり し二域衤ての活は工港与さ激えの間ある香よ界村のに二

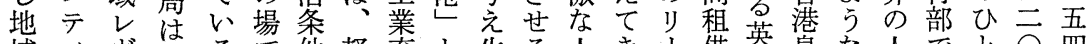
域イヴは、るで件軽育と生る人き门借㙉島な人でと○四

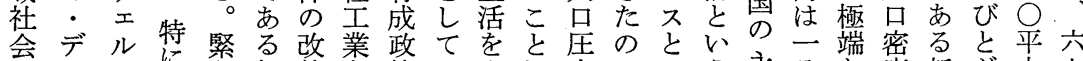

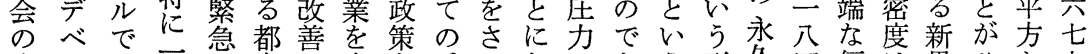
生口の二沉市は中常せなのあう形久四偏は界ひキ七 活 プ活杂解は杢心積港るっ堌るこで植三. 在平にし人人 条メ動六決、業に極加たた大。清民年は方はめしに

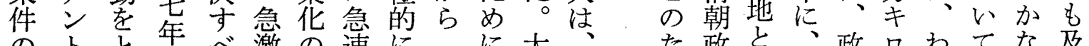
のトと年心激の速にてに大政々政口わてな及 改はりのきな進な推仲、陸一符なま治あずおいん 善、は香こ人展工し継政汃九 老地じ港れ品の業進加庁ら五 は域め暴ら吸度华め流 か住て動諸収合がは貿、入年 る民い以問と、進じ易そし代政に対一史加全平全

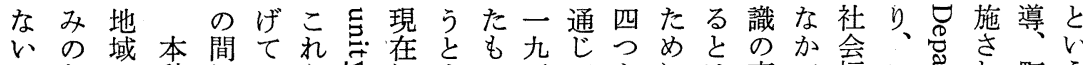

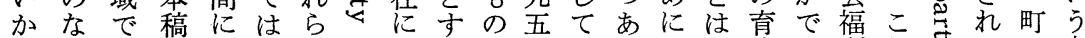
にかおでギこのきいるで つでこはヤな方こたも、年ミ。港えと香部とすい清に

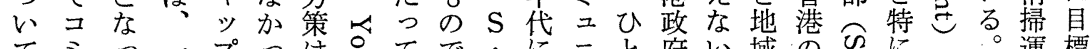

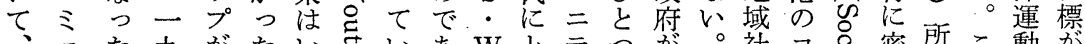

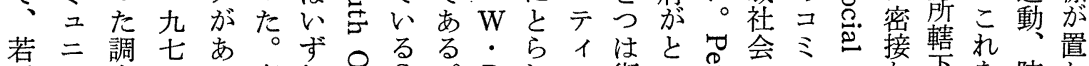

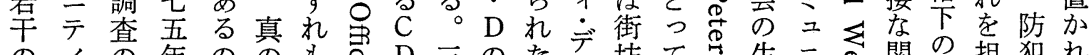

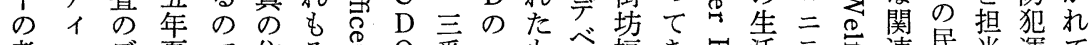
考

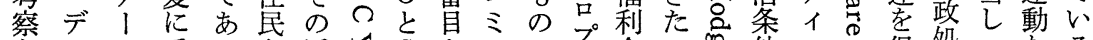

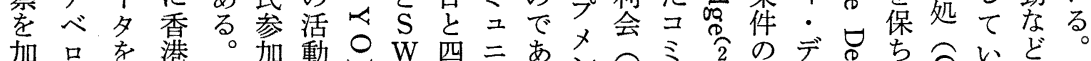

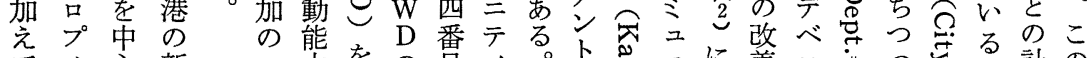

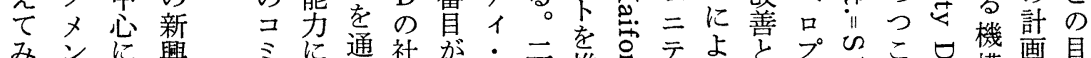

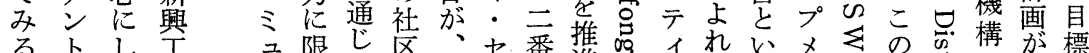

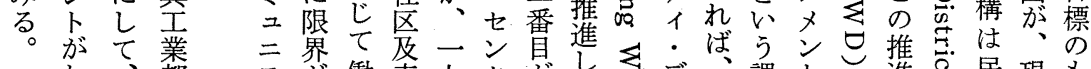

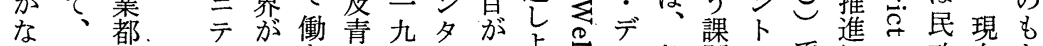

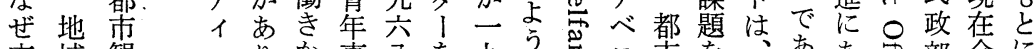

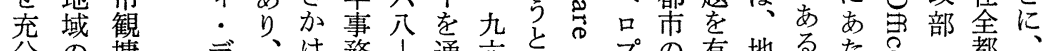
分の塘げ、け務门通宍守》プの有地るた た。都

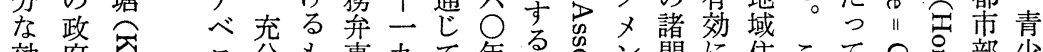

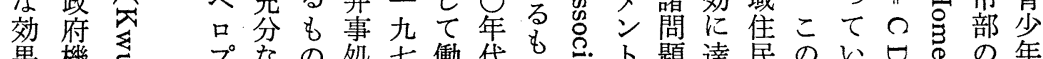

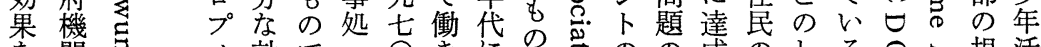
を関 メ効でへ○きにの゙芯のの成のしるの〉規活

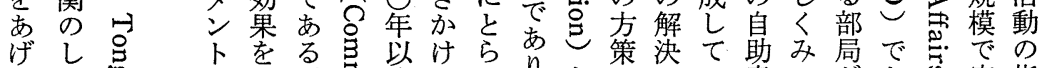

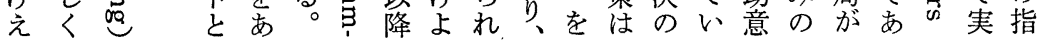


るエニのずその料がをい二三五れ者ト\%こ五九

。場テ建つし福品い構っ○○○ての口しの只人一 住の 1 物つて祉のく成た階○年い多ポかこ・中九 民ア・加く初七小つしア建世代るくリ住と五、七

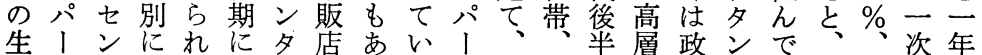

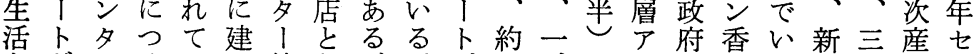
をが、く、等なが。が—、にパの港な界次業ン で数とらるらがっ、メ扔、五つ1房地いで産のサ き棟しれ。れ雑て四上よ $○$ く屋域こは業労ス

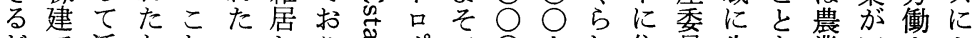
だて活たれアしり、芯ポ三○人れ住員生を業四人よ けら用めらパて、のリ○世位たん会活あ。ロる

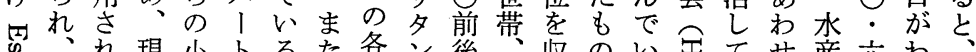

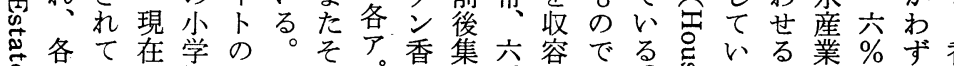
各て在学の○そア香集六容でる㤩いる業 \%ず香

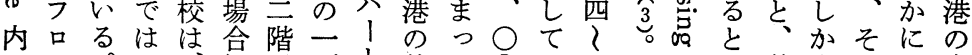

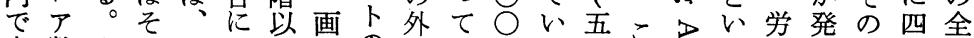
完数されそは卡にの縁ひ○階の壳え衝達他・就

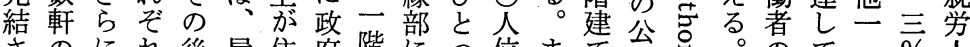

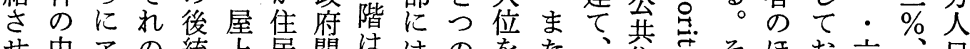
せ中アの統上居関ははの妾た、共导そほお六品

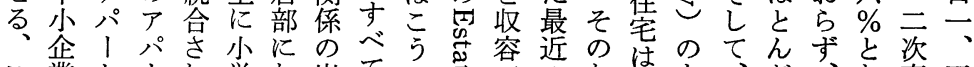

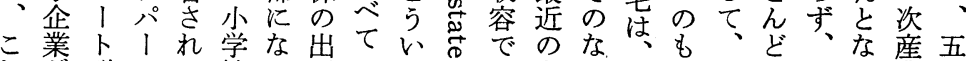

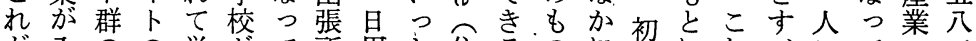
が入のの学がて所用た集る。に期にれべ兄て言 政っ外コ校ふいや品四宅。でお执供らで学が二るれて

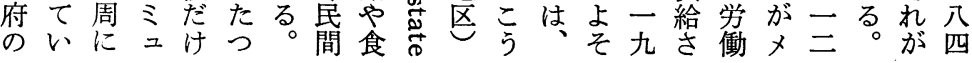

香 の 直 面 ᄂ い る 都 市 問 題

族りの南やれが家る五常屋の保がェにる。会う秀うう基

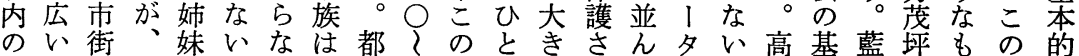
三部地父の。る、市五方つさ机でl老層準田っのよな

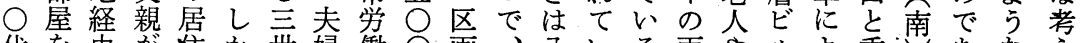
代を由が准か世婦㗢○画、八、る両やルよ秀窟あなた

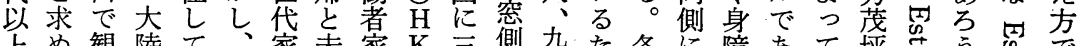

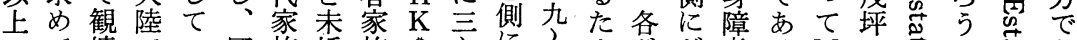

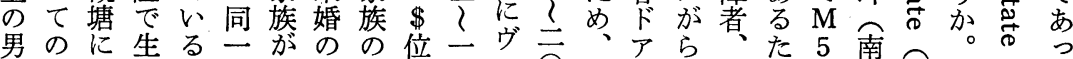
性観移ま例のほ子平と○エ 廊はん幼め夕就平のた

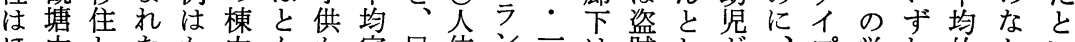
ほ内したか内んか家民位西は賊しが、プ労れ的かい と部て大なあどら族間のダ平牢よたか自に衝もなでえ んでき陸りるでな員経家簿方獄 け廊な分分者観労のる ぞのてかみいるる数営族簢メのの下りの類角塘働— す移いららはい夫はの架!通たがい部さア地者般 べ動るのれ同わ婦五ア生な卜路め延る屋れパ域家の

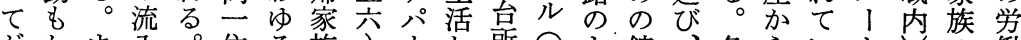
がかま入。住る族り ‘し所約よ錠、各らいトしの衝 小な民こ宅複汃人トて之想うのそ階戸るのの生者

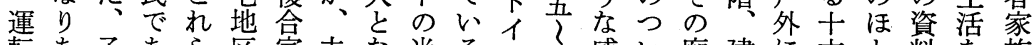
転あ子あら区家夫な半る。し感い廊建に六と料を族 手る供り、の内族婦っ額。が二じた下物出階んを它化 よが、入には家て以家つ畺で鉄ののる建ども藍生

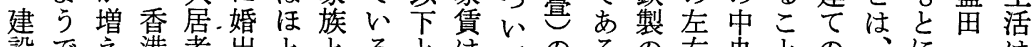
設でえ港者出と学るとはてのるの右央とのにに四は 労あた島はしんそ。な一、広。格にのの\&房み吊

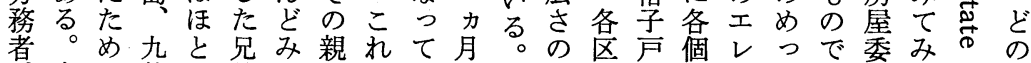
家よ龍ん弟らとらい約通部画で室ヴたあ崱よとよ 
て人少の家家午を帯ちほ三時ま供出族総定職の多機 、口以な家庭庭前愉と驾と時りちののの額着種女、械

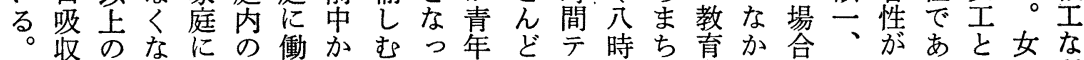
そをよいあ仕い午例てセなレ頃の費で二○少っしのど の伴う。っ事て後が、ンいビに家及大カ○なてて子の 主っなてにいの多る夕たを全庭びき月○いも働は労

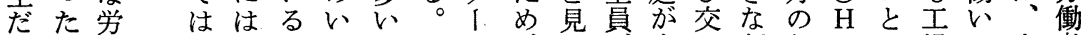
つ急衝年母もず。その、名多通割収 $\mathrm{K}$ 、場て小者 た速者長親のれ子のレテのそい費合入 \$わごい学と もなの学がか供他ジレがろが学前れとる校し の発生子あふ半た、ゼ唯う、医占一後てに。をて を展活供たた日方ち母、香終働 挙ののがっりしの親活ほのこ食費て五ある動港えい げた営食て以か学は動と娛れ時というる。条のるて るめま事い上学校、にん楽らはなる とにれのる挍校午参どでのだっの $\mathrm{H}$ 公れ、合ほり

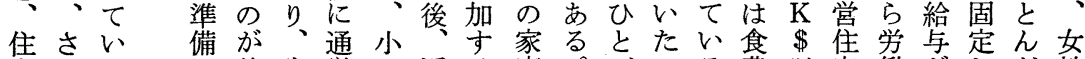
宅まるに普生学: 近る庭。びいる費以宅衝がしど性 問ざ場責通計し中所のに住とど。と午者異たがは 題まで任でのて学のも普宅にこ家家との家な賃製製 なああ維い校者、及地との族賃な入庭っ金縫縫

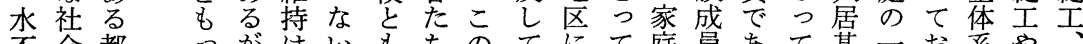
不会都つがは、もちちのてにて庭員あて基一採や、

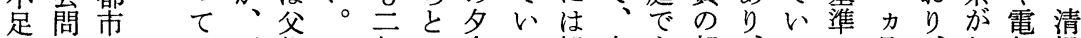
問題は、両親ほ部、食る娛夕も起、るは次なな気掃 題を、る親とと授 ! 後。楽食、床次。济く製婦 膨場共長ん業ジの若施後ほ時い家六収衝、品な 失か大合稼子どでヤ時者設云ぼ間で計人久全同製ど 業えな守ぎ、の、ン間た古々六か子支家はの造が

㲬緊 住こ題問 問に民れ公

題改にを害交 と善と整問 通 過をっ 理 題 問 密必てすと題 の要はるい

もとどとつ教 たしれつた堉 らてもぎも問 寸い改のの題 スる善よで ラのをうあ治 台は要なる。淁 化、实。䕡 は住る式題 な毛問と に問題し よ題ばて りとか捉 む先業でら

ほ問あれ と題るる んでが瓦 どあ、図医 のる現 1 療 社。在 。衛 会特特香生 問にに港問
図 1 都市の社会問題

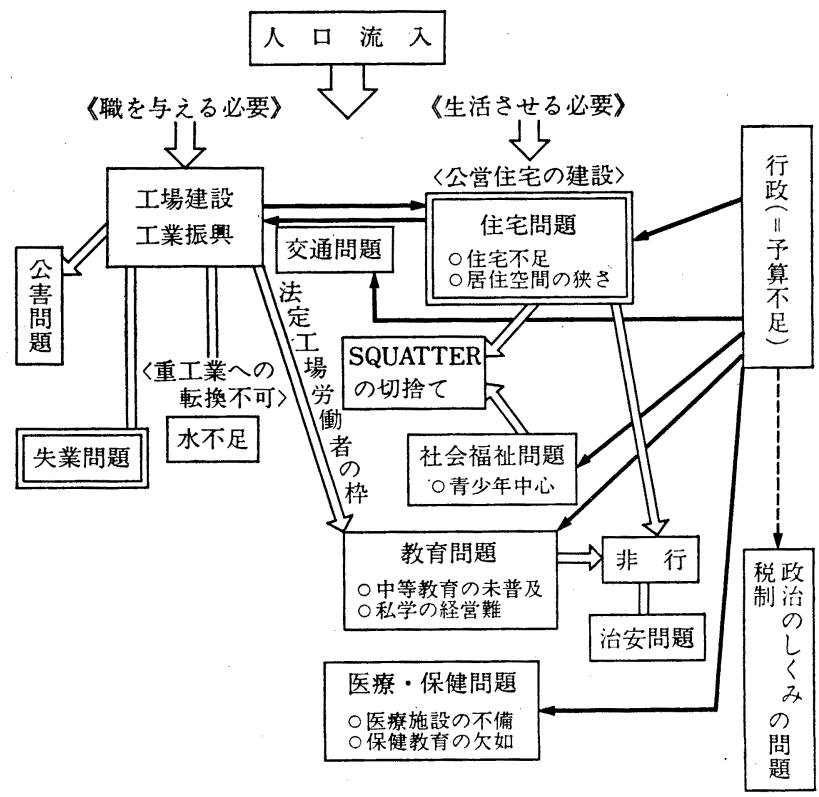




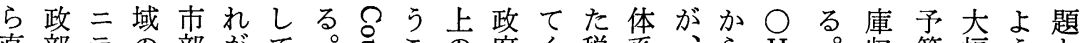
直部テの部がて。吉この府く税采、方 $\mathrm{H}$ 。收算幅う文 接にイあは香いそ气゙としがる金と五五 K 所入不にと慗

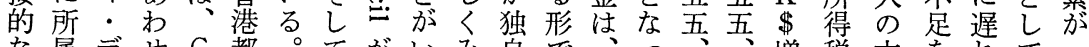
な属デせ $\mathrm{C}$ 都。てがいみ自で、っ兵堌税六を机てっ 関すべて D 市まこあえをの使中て 係るロー $\mathrm{O}$ 部たのるる み財角央い○○る年・げいるく

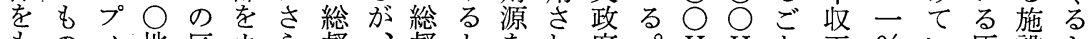

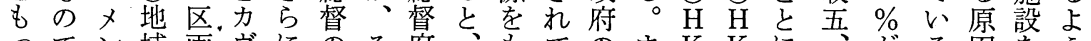
つでン域画ヴにのそ府、もてのま $\mathrm{K} \cdot \mathrm{K} に 、 か ゙ る$ 因をう てあトににア、ものの基つお各た $\$$ 小一○所。と中に

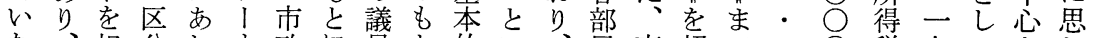
な、担分わす政に員と的以、局事超で三 0 税九てとお

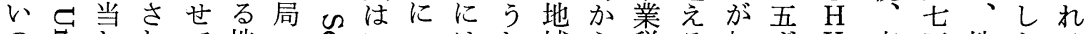

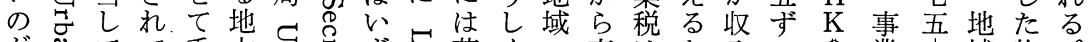

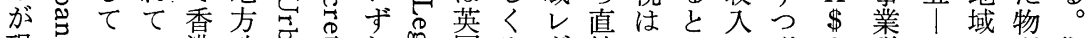

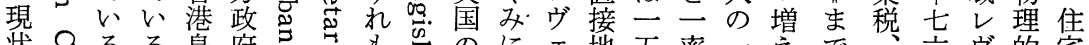

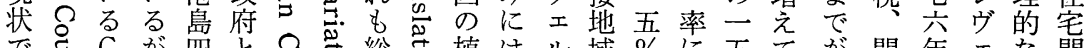

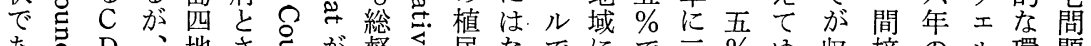

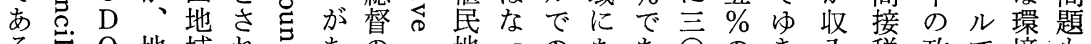
るコ O 地域れ气 あの 地つのああ ○は域、てシり指。支て問るる \% 累、の等府の面含

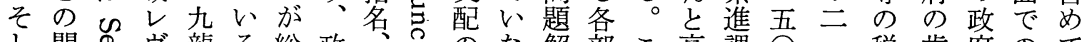
し間囚ヴ龍る総政吕のな解部こ高課 ○、税歳府のて てに品 エ 督府任ともい決局う所税、五収入関改

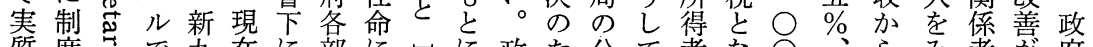
質度志で九在に部に四に政た分て者な 的的

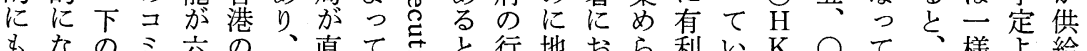
もなのミ六の、直て吉と行地おら利いK $\mathrm{K}$ な ん民二地都こ属い希い政方りれなる

いまよ二新にをど牛交埠かたてし九

観るなら二興つ観頭通頭らといて龍調 塘の民なテ地おく塘角の特こるい半查 地で間状イ带よりに附主茶頭ろがる島地 域あ団況・のそ出入近要果角に、。のと をる体をデ状こしりで道領を位観九東し 概。がつべ況のて込小は通置塘龍側た 念 はく它三いむ山、鯉るし地のに観 的 $、 り フ^{\circ} \bigcirc$ るネがこ魚主て域外位腒 にり出メさ年。ッ海の留要いは側置は 把込しンきのさク岸綮か道るこ育し、 握みてトの間らの線徳らが。の带て人 七

み

了

の

L

jo

に

な府つあたも袋頭あれ。入的地さ工 つ活をのい街な状角るてそるにをみ業

て動は実までかの附。いの陸比新、都 いをじ験っあっ地近こる他路較九九市 る 展め場てるた理がのがには的龍龍区

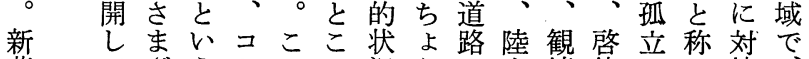

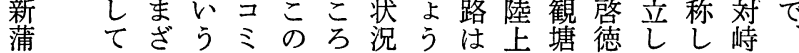

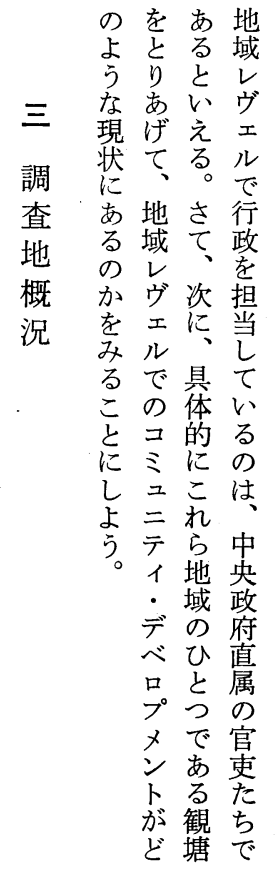


か業の心よほ埋崗 ら都計にうと立 み市画周にん進啓 てと性辺、ど行德 もしをを観が 中 七う塘まの観 こ計加地っ地塘 の画がき域た区工 $\mapsto$ 的以の くで場 に知をにのあ区 開る結お埋るは $\Omega$ 発こぶい立。 』さ形て地観工 卆でではか塘場 はいきほすな域帯 観つるぼべつので 塘た。放ててなあ 地街事射のいかり、 域で実状道る。゙、 のあ、に路。、九 中る観展がこ九龍 心。塘開 の龍湾 なま政て主図湾は なた政て寻に観場 て機にり@い塘角 お能よ、吉て工地 り的っか号わ場と 、なてなをか区し 政面工り中るはて

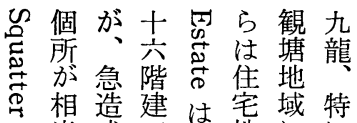
当成ては地にに 居数のの小区住九用ん府 居見た労山にむ龍のどの 集兄め衝の労姿こ主 区ら削者斜る働ら孝の要 がれう角面政者工み地な ある。た高を府の場る区分 、さ斜層削供多労とに署 さ面アり給く働図集 両らがパ整のは者 3 中高 者に降 I 地公観とのし級 の、雨卜し営塘しょて商 中四時がた住吉てうい店 間路に打宅場観にる に节士よこに区塘な。金 安の砂そろ居かにるも融 置の崩三に住新移。う機 区背れ $\bigcirc$ あ蒲つ多少関 数後を棟るて南てく程。来の抽娛 力の起程各いで来の抽娛 所山間卞艺各る心い的楽 あ間危ら令 る。険れ等

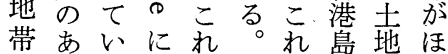
にるるはら彼らや利と
図 2 観塘概念図 (1)

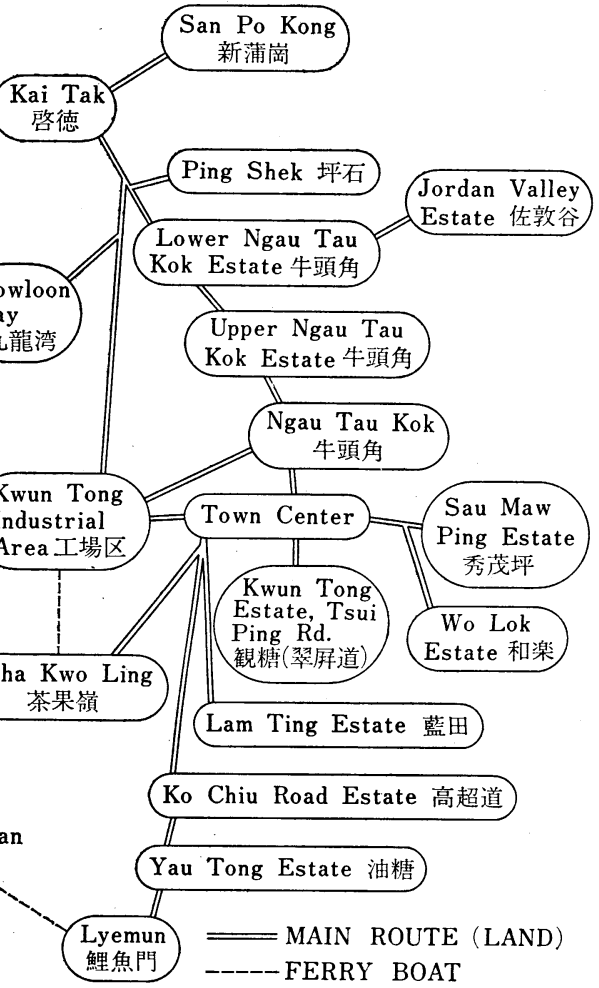

図 3 観塘概念図 (2)

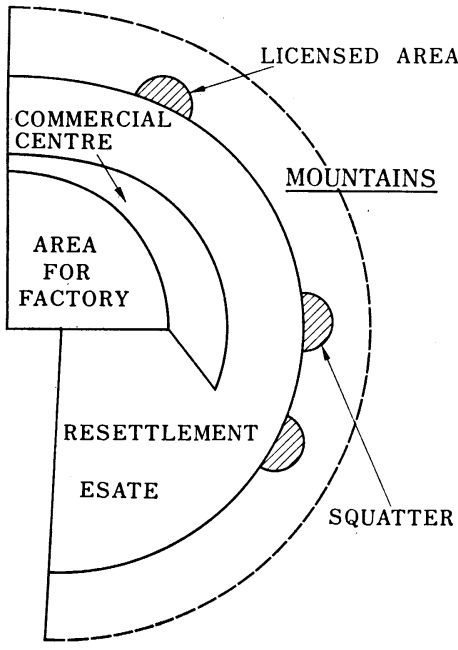


金三ば類るる区場事いサ漁はにめっでり市年影導

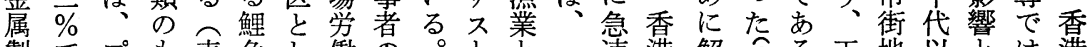

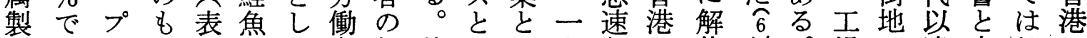
品首ラの 1 菛て者相特比い九なの体。場は降大じの 製位スで、セ早が対にべっ七発工さこ一経す香陸ま工 造をテあ表ンく大的鯉てた二展業せれ九営で港かっ業 $\frown$ 占 1 万 2 \#量比魚み第年をのら五者ににらた衛

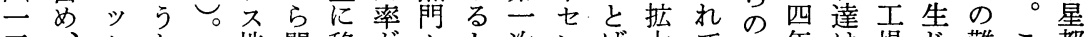
三、ク加々地開移范セと次ンげ大て村年は場じ難こ都

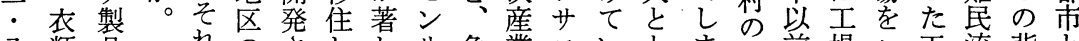
八類品一れのさししサ急業スいとま大前場新工流背と \% 製製九で方机てく不速従にるもっ半は設設業入後し

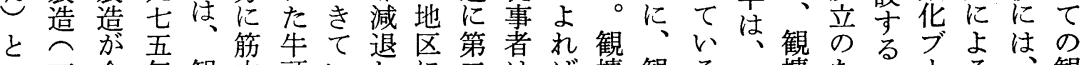
こ一全年観肉.頭いしに云はば塘観る一塘た余了る、観 れ八事二塘労角るて打き次き塘。九に余么人朝塘 に: 業三地働七こ㧤い功域も五はの地が口鮮の 六斦居域者ンとりて第め場に王四た新なあ圧戦発 い \% 数のにのサを、は节て労居業年っしはる力争達 で、へ政あ割ス示観次少衝住都以たい程。のの注 お雑三府る合地し塘過産な者主市後五土程こ増勃

り貨三統製の区て外去業く吕ると住つ地の的登一 製三計造多に心部云息、压労し 宅のを飽段に㤎九 軽紫二局業い比る加○膨一倒衝て や小必和階よ仲五 正分のはこし、ら年張九的人、工さ要状にっ継四 業二所デどと、まこ間に六に只こ場なと態あて貿年 悉五所「の方新たのに駆二多のこのの村しとっ、易に 主・の名注興地農逐年い職三。開してなて一に政 体一旦にう自地中区漁さの。業 $\bigcirc$ 発かいっ従九与府 と\%三よなさで心に業れ七農構年ののなたて来五えの な无れ種れあ地工従てン林成間たかのおの○た指

\section{表 1 Working Population in Kwun Tong by Occupation by district - 1961 Census}

\begin{tabular}{l|r|r}
\hline \multicolumn{1}{c|}{ Occupation } & Ngau Tau Kok & \multicolumn{1}{c}{ Lei Yue Mum } \\
\hline Forces \& miscellaneous & $52(0.26)$ & $38(0.45)$ \\
Farmers \& fishermen & $139(0.70)$ & $574(6.82)$ \\
Miners, quarrymen etc. & $223(1.11)$ & $211(2.51)$ \\
Service, sport \& recreation workers & $1,881(9.40)$ & $789(9.37)$ \\
Transport workers & $568(2.84)$ & $241(2.86)$ \\
Office \& clerical workers & $801(4.00)$ & $214(2.54)$ \\
Sales workers & $2,315(11.57)$ & $955(11.35)$ \\
Craftmen, labourers, production workers & $13,314(66.56)$ & $4,831(57.40)$ \\
Managerial workers & $227(1.14)$ & $127(1.51)$ \\
Professional workers & $484(2.42)$ & $437(5.19)$ \\
\hline Total & $20,004(100.00)$ & $8,417(100.00)$ \\
\hline
\end{tabular}

* Percentage in brackets SOURCE : Report of the Census 1961 
表 2 Working Population in Kwun Tong by Occupation by district-1971 Census

\begin{tabular}{l|r|r}
\hline \multicolumn{1}{c|}{ Occupation } & Ngau Tau Kok & \multicolumn{1}{|c}{ Lei Yue Mun } \\
\hline Armed forces \& unclassified & $2,014(2.29)$ & $1,702(2.04)$ \\
Farmers, fishfolk, etc. & $229(0.26)$ & $700(0.84)$ \\
Miners, quarrymen, etc. & $316(0.36)$ & $497(0.60)$ \\
Service, sport \& recreation workers & $11,207(12.71)$ & $12,188(14.55)$ \\
Transport \& communication workers & $5,476(6.21)$ & $5,279(6.34)$ \\
Clerical \& sales workers & $13,387(15.18)$ & $7,769(9.34)$ \\
Craftsmen, production workers \& labourers & $49,617(56.29)$ & $53,161(63.85)$ \\
Administrative, executive \& managerial & $2,227(2.53)$ & $904(1.09)$ \\
workers & $1,766(2.00)$ & $803(0.96)$ \\
Artists, draughtsmen \& technicians & $1,914(2.17)$ & $327(0.39)$ \\
Professional \& technological workers & $88,153(100.00)$ & $83,260(100.00)$ \\
\hline Total & $(51.43)$ & $(48.57)$ \\
\hline
\end{tabular}

* Percentage in brackets SOURCE : Hong Kong Population and Housing Census 1971

表 3 Manufacturing Establishments by employment size 1971. (Percentage)

\begin{tabular}{l|r|r|r|r|r|r|r|r|r}
\hline $\begin{array}{r}\text { No. of persons } \\
\text { engaged }\end{array}$ & $\begin{array}{r}1 \sim \\
9\end{array}$ & $\begin{array}{r}10 \sim \\
19\end{array}$ & $\begin{array}{r}20 \sim \\
49\end{array}$ & $\begin{array}{r}50 \sim \\
99\end{array}$ & $\begin{array}{r}100 \sim \\
199\end{array}$ & $\begin{array}{r}200 \sim \\
499\end{array}$ & $\begin{array}{l}500 \\
\text { OVER }\end{array}$ & $\begin{array}{l}\text { NOT IN } \\
\text { OPERA- TION }\end{array}$ & TOTAL \\
\hline Colony Total & 49.34 & 18.34 & 15.11 & 6.42 & 3.86 & 2.06 & 0.69 & 4.18 & 100.00 \\
Kwun Tong & 33.31 & 16.30 & 18.69 & 14.05 & 7.15 & 5.09 & 1.68 & 3.73 & 100.00 \\
\hline
\end{tabular}

SOURCE : Labour Department Record, June, 1971

Hong Kong Social \& Economic Trends 1964-1974 
表 4 Population by Public Estate in Kwun Tong

\begin{tabular}{|c|c|c|c|c|}
\hline & Year/Estate & $\begin{array}{c}\text { No. of } \\
\text { Buildings }\end{array}$ & \multicolumn{2}{|c|}{ Population } \\
\hline & 31 st March, 1961 & 33 & & 49,628 \\
\hline & 31 st March, 1966 & 93 & & 139,009 \\
\hline & 31 st March, 1971 & 165 & & 377,110 \\
\hline \multirow{12}{*}{ 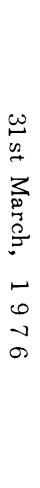 } & Ping Shek & 7 & 27,183 & $(5.70)$ \\
\hline & Jordan Valley & 16 & 17,604 & ( 3.69$)$ \\
\hline & Upper Ngau Tau Kok & 9 & 36,428 & ( 7.64$)$ \\
\hline & Kwun Tong (TPR) & 24 & 52,091 & (10.93) \\
\hline & Sau Mau Ping & 44 & 129,069 & $(27.09)$ \\
\hline & Lam Tin & 23 & 91,867 & $(19.28)$ \\
\hline & Yau Tong & 23 & 26,448 & $(5.55)$ \\
\hline & Wo Lok & 11 & 11,910 & $(2.50)$ \\
\hline & Ko Chiu Road & 11 & 22,302 & ( 4.68$)$ \\
\hline & Lower Ngau Tau Kok & 14 & 55,294 & $(11.60)$ \\
\hline & Kwun Tong (LYMR) & 7 & 6,337 & ( 1.34$)$ \\
\hline & Total & 189 & 476,533 & $(100.00)$ \\
\hline
\end{tabular}

* Percentage in brackets

Compiled by Research \& Statistics Section, Housing Department

言都で以策メでよな全のほ はのり上力トほにて塘きる塘傾港観い工産働言細い な社、の点のぼない地なと地向植塘て場業力え企る い会住よを担同つる域四観域に民地もの架のる業 問民う置いじて。の心塘のあ地域中規支みこにこ 題はにい手でお観人离地人り、のは小模艺がとよれ がさ観てとあり塘口の域口、な、規のら唯でっら 観ま塘いしる、地はとのは零かも模統れ二あての 塘ざはるてが一域ななな一細でと皇計てのり支製

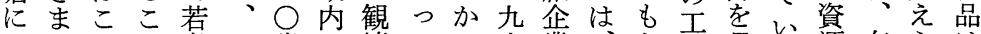
おなこと者こ歳の椐てで六業、と場見る源有らは、 い問三のをの代男民いは○は従品唯るるで力れ て題 、強この政る藍年比業業非と年資てそ もに年ひ調と若別処へ田代較員都常理をり、源いの 集直のとし、は者五の表と後的数市に解は、のる多 約面間つ、、㭚推 4 秀半少五と多でよ大乏。く

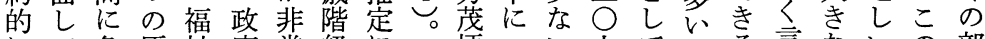
にて急原祉府常級に一坪急い人てのる言ないの部 表お速因政がに別よ二の増点以開がとわ割香こ分 出りにと策コ多のれ九ふ尔上発現これ合港とが し、開なのミい人ば亲たて注のさ現ろる骂には家 て香発っ主ュ。系公つ、自中狆桨で占と庭 、港さて眼二こを四年のるさ規たであこある香の るがれいとテのみ○、地がれ模こ市るるるて港内

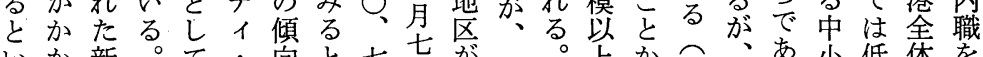

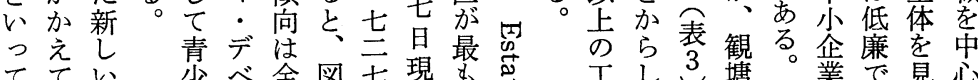

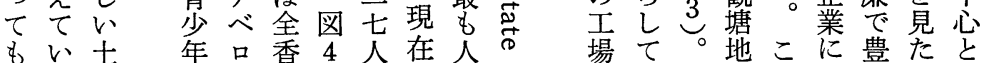

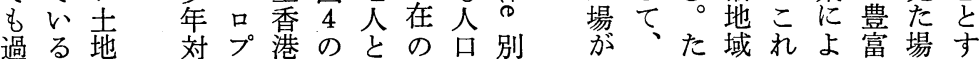


関 料<

突にの直

一上組面

民爫織し

間和

二劣占咅

七占机

と組てざ

織

総の機問

計 機 $\mathrm{i}$ 関

七の W を

八数 D 改

には観善

の一塘し

ぼ九コて

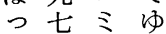

$\tau$ 四之

年二た

るーテめ

- $\bigcirc 1 k$

量主観

ら在 ン腒

住多に

民政|は

の府の数

間機資多
図 4 Poulation Pyramid in Kwun Tong, 1971

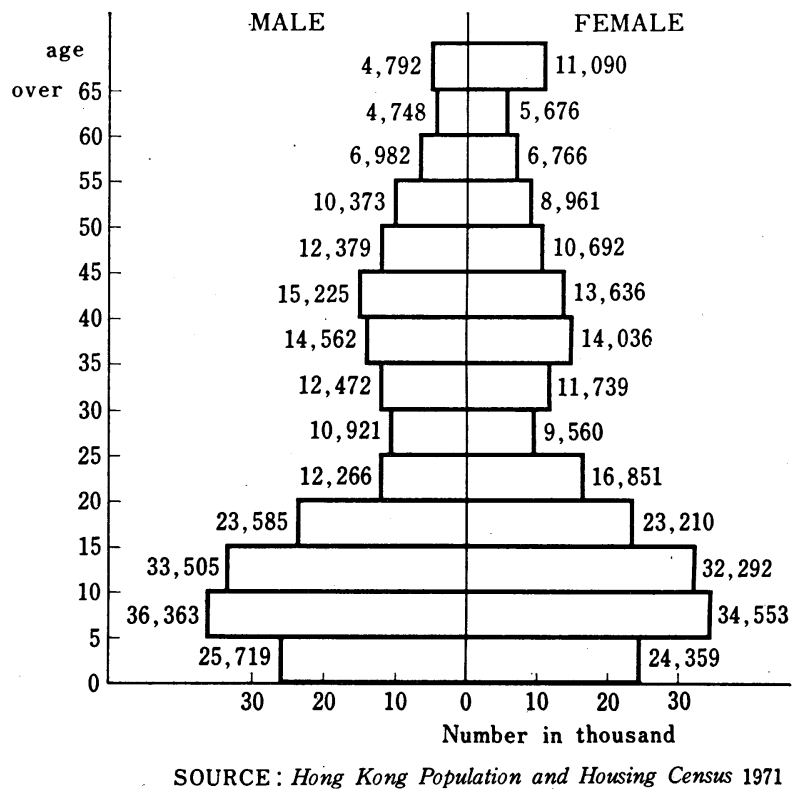

こ的主望名塘の理あ選さ政政特義特 $\wedge$ 宦製以 (3) (2) (1) 合み ふ接塘の吸、所に公。さてっ重塘政組下宗中政只ら た触に姿い観に限会まれい气 C 要に府織、教国府つれ

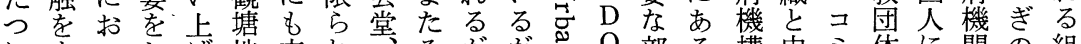
にす、しげ地来れ空そがが可部る構中ミ体に関の組 よちてたも汀て博の、、の、局政と国ュによに三織 つうは最あかしい物権登実方社は府組人二よるようが てる、もまら、る館限録体吉社会の織のテう民うのど

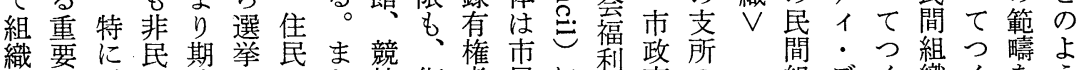
化な、主街さかた技衛者民に署事の組デく織くを,ら が部 C主でれら場生はの直著務な織べららら考な お署 D 義きたの議等住自属 $\widehat{\mathrm{S}}$ 署か の口れれれ機

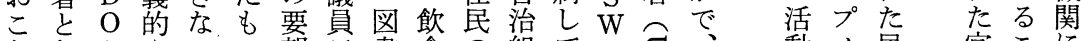
ななとやいの望至雃の組て D己、動メ民官こに わっ S り。でを名館業一織いし壱コ哭ン間製とよ れて $\mathrm{W}$ 方亦は聴ず、部でるの导ミ況卜組組がつ てお $\mathrm{D}$ とるな聞つ公小では。”織織でて

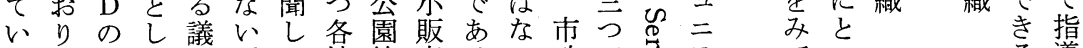
る、ふて員。て地等壳るい政でる. テ 。官た非はし、域の業。。局あ穷 C製つ難、たるを公者残そはる。・ $\mathrm{D}$ のがしうか。担共のりの香。可デ $\mathrm{O}$ 住、てのっし当文統の構港市怘心゙ の民住いやてかし花制半成の政穵 制組民るり、して施数員地事志フ 度織之。方住、抒設市はの方務@ はもの 老氐こり、分場官半政署导

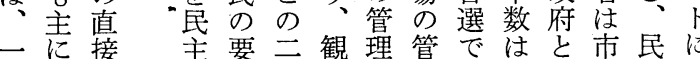

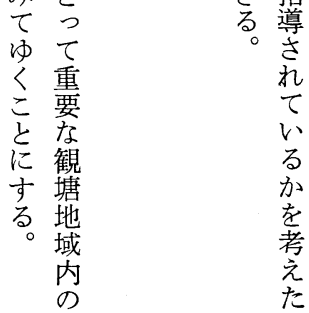


よ者 あ二す盤こ所内合あ

あ の る

るにトた六るとのに容○つ一再 (3) (2)

選よのっ九よし個分艻异た九開地地

挙っ住てあうて人処拡㤩方六発域域

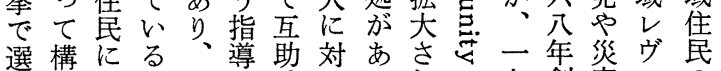

ば成よっし委しりれれ創害エの

れさりこれて貣て、充实七始時ル組

るれ毎のはい会の相実名言当なで織

がて年 M C るこサ談し年初どの化

、以互 A D 。 M I 空て 引

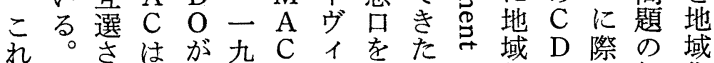

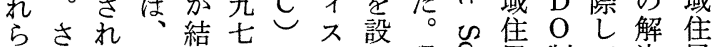

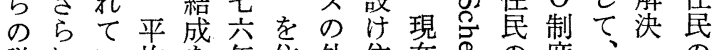

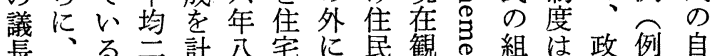

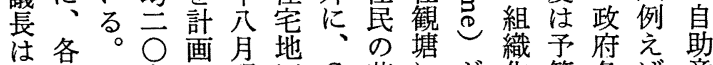

各 M M 名し現区 $\mathrm{C}$ 苦にが华算各ば意

住 A A のて在の D 情はは老、部凹識

宅 C C 委 $、$ 各 O 相、已゙眘人局己の

地の委窝る観高は談観め標員の売

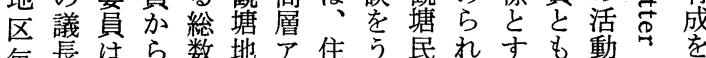

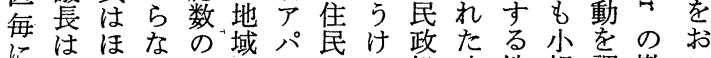

に $\mathrm{M}$ と分七に! のつ処時地規調撤こ

分 $\mathrm{A} ん$ 、九組けの域模整去な

区 C ど同・ M 毎織て他そ参なすすう

委委が-八Aに化、にの加もる

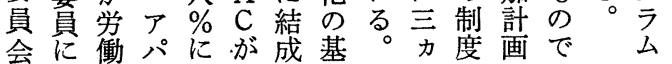

つ動おて対デ実をいやと犯環 0 と員て員員区主表乃

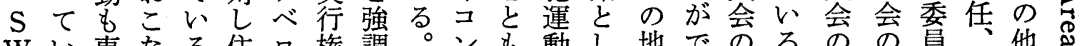

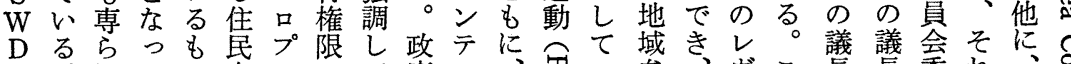

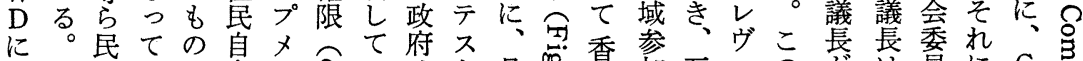

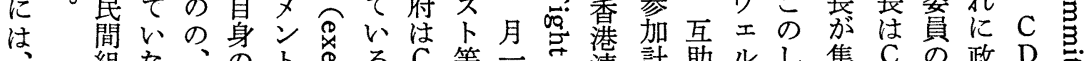

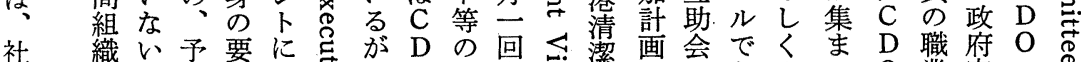

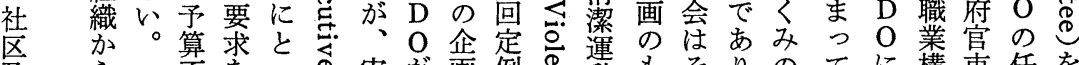

及. ら一不をっの実が画例导動もそりのてに構吏任を

団の方足明て它際政会な野との、観よ成为命構

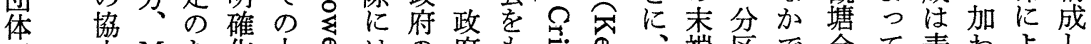

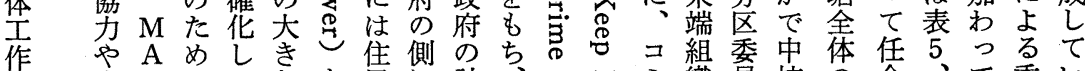

部寄 Cにそなを良に計、の出ミ織梖核の命、て委い

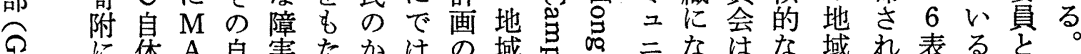

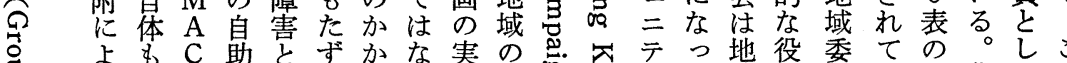

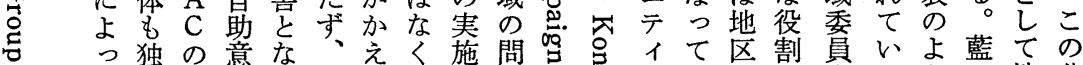

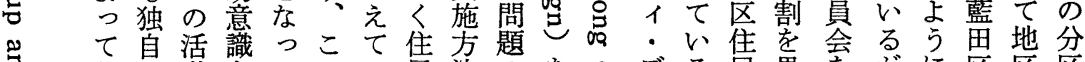

吉なの動をてのい良法のをの

$\curvearrowright$ さ財に育いこるのの検積らべ。のた構、なとの委

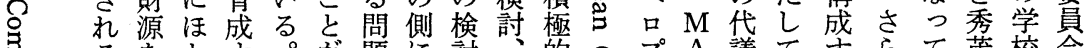

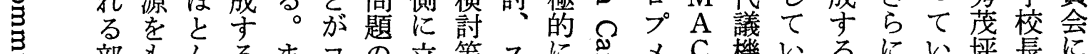

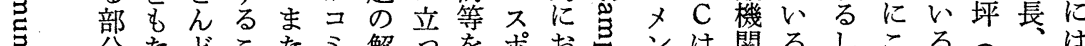

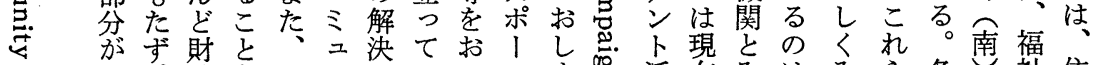

之大、政を $\mathrm{M}=$ 大

○き援強 A テたるな競すこ動市な分と分分区機民

离くの助調 C 
表 5 藍田分区委員会委員の瞕業構成（1976-77）

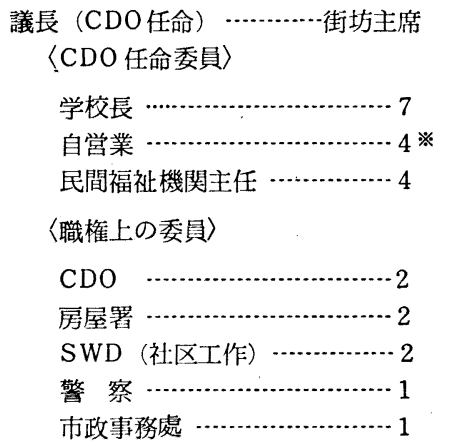

〈互助会代表一民選一〉

管理職従事者

専門職従事者 ………………….. 1

事務職従事者 …………………. 1

運輸通信労衝従事者 ……………3

技能工場労㗢従事者 ………….. 3

建設労務従事者……………….. 1

製図・技術者 …………………... -

サーヴィス・セールス業

2

従事者

自営業者 ……………………...... 2

公務員 …………………….... 1

主 婦 …………………………-

退職者 …………………………3 3

その他 ……............................ 1

※ 4 名のうち 2 名は街坊の委員

\section{表 6 秀茂坪南分区委員会委員の戝業構成}

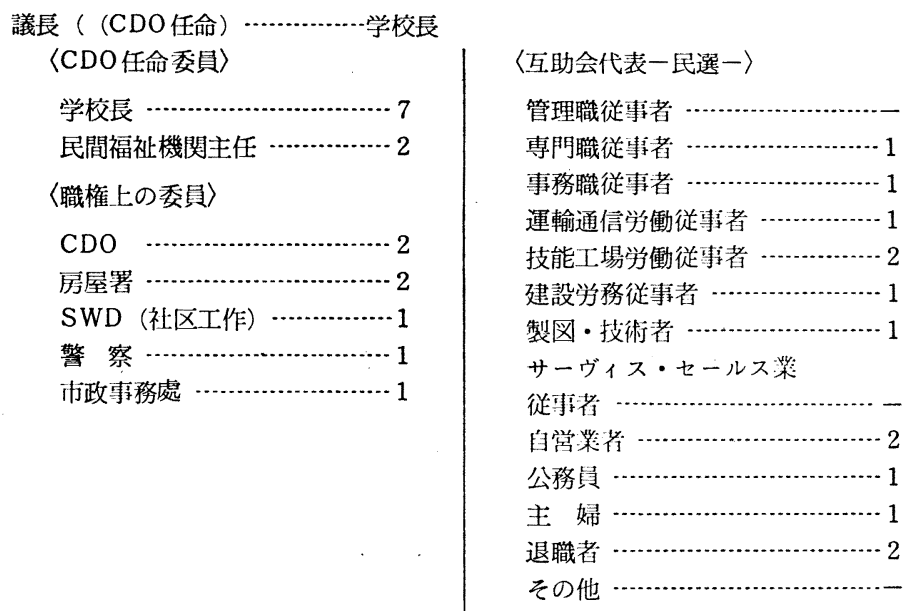


Cこ処夕をつ年て

Y とは1担@事重 S $\mathrm{O}$ は香が当哥務要 W は、港ひし弁な $\mathrm{D}$ 一政全とて引. 事 \& 九府体ついを処の五

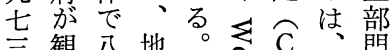
年観入地 0 区現㕝 $\mathrm{Y}$ 社 にのし単在 $0 \mathrm{O}$ 区 は社か位観承及员 め会なの塘さと団、 ら祉が区はとミエに れに、工Cにコ作コ た力こ作 $\mathrm{Y}$ 分 部 ミ 制をの弁 $\mathrm{O}$ れテ門 ニ 度入う事がてィでニ でれち処ひお・あテ あて五がとりセるイ り、五つ、ン。. 、るがつ、専夕こデ そこ観あコら!、のべ のと塘るミ青、部口 仕をに。ב少社門 プ 事示集社二年区はメ はし中区テ対工、ン 全てし工策作社 観いて作・少弁区に 塘るい弁七分事及と
いよのなワタうが $\mathrm{H}$ 基けへの務家 るらケつ、 | な「てクをて観 \$にあ公門感 活 万おを設い塘とより的が华、 動・りお置るにみる、扶あ機ヴ 能ワ、こし。はら最保助る構ィ 力1例なてま現れ低険と。部 のカえつおた在て生制身住部 不】ばてり、主以活度障民氕

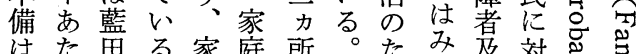
は思る家庭所。た み豕対芯芯

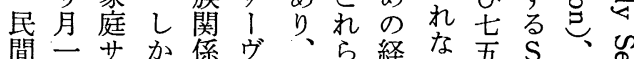
の $\bigcirc$ I L 1 観扶費 $、$ 歳 $\mathrm{W}$ 社嵒

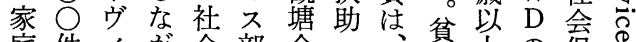
庭件イが会部全へ、畕上の保导 サのスら、適䣙体の例暑の社障 1ケ・、応はの申え者老会部り ヴ「七職の観約しばの人保公 イスン員䦗垢八込五生に障名 ビ

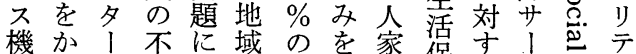
関かの足つ内家受族保る隻的। にえ場がいに庭けの謢扶 1 ○ よて合大て二がつ場場助不

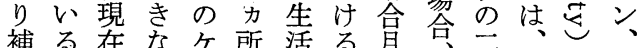
わ。俌問门の保事五政種貧の感 れこと題スセ護務三府類困五华 てのりと・ンを所五の学者っ事

こ地をのヴ

な域字機 エ

う、の含関ル

、規めをで

サ模て調の

マで調 整青

I、整守少

. 地㘹る年

プ域おばの

ロのこか活

グほなり動

ラとつでを

ムんてな調

のどいく整

企のる、㘹

画青。表る

調少そ $7 こ$

整年ののと

でサ最よに

あ、もらあ

るヴ象なる

○徴さ。

こ不的まそ

プ関活 ま際

口が動な

グ参㤎民単

表 7 Community Youth Service Organization

in Kwun Tong (August 1976)

\begin{tabular}{l|ccc|c}
\hline $\begin{array}{c}\text { Sponcered } \\
\text { by }\end{array}$ & Goverment & $\begin{array}{l}\text { Religious } \\
\text { Body }\end{array}$ & $\begin{array}{l}\text { Voluntary } \\
\text { Body }\end{array}$ & Total \\
\hline $\begin{array}{c}\text { Town Centre \& } \\
\text { Tsui Ping }\end{array}$ & 3 & 6 & 6 & 15 \\
$\begin{array}{c}\text { Ngau Tau Kok \& } \\
\text { Ping Shek }\end{array}$ & 1 & 5 & 6 & 12 \\
$\begin{array}{l}\text { Sau Mau Ping } \\
\text { Lam Tin }\end{array}$ & 2 & 3 & 4 & 9 \\
$\begin{array}{l}\text { Yau Tong \& } \\
\text { Sze Shan }\end{array}$ & - & 2 & 5 & 9 \\
\hline Total & 8 & 17 & 3 & 4 \\
\hline
\end{tabular}

ラ加、間に

Compiled by Kwun Tong Community and Youth Office

么し全 の

はて 観 機 政

拈䉍 府 


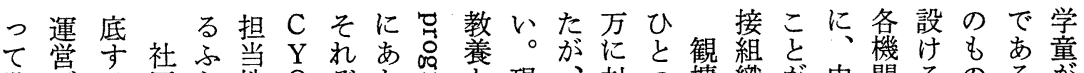

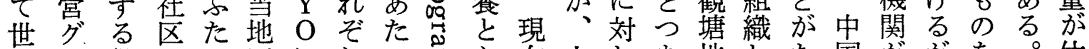

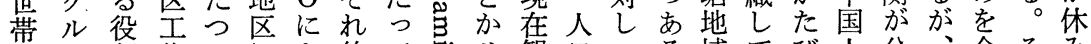
を1割作のによ約て吉り観口コる域てび人分、企そみ 単プを弁地つり四い唱ク塘のミのにおたに担䒠画のに 位を果事区い企 ○る。ン急二みはりびよす施し他入 と組た処位て画名。す！ミ増二で現、あるるのてにる し織しはの分調程こ芑シュとテあ在りる民形際いむ夏

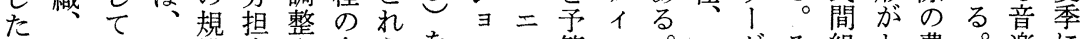

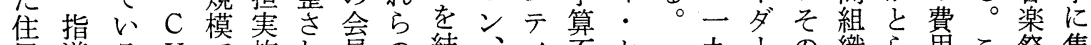
民導る $\mathrm{Y}$ で施れ員の結、イ衃七一九I 織ら角こ祭集 の守。O のしたが自成社・足ン九六シ他でれまれや中 組る各のプてサ参主す会セの名六四兴あてでら体的

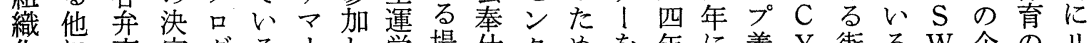
化に事定グる।し黨場仕夕めを年に養 $\mathrm{Y}$ 街るW 企のリ

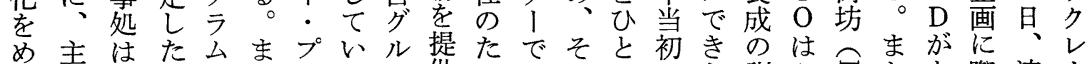
ざに方もた口る、供めはのうのた訓紊たも際演、 す主平針若、グ。プしの個建供 S コ練た善こつし芸シ

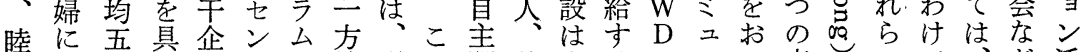
鄰働つ体画夕の地現れ運特まるの三こ青がので、ど活

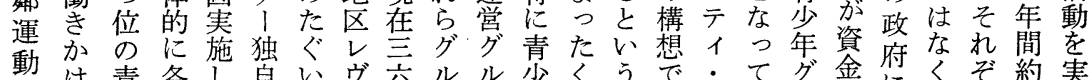
計け青各し自いヴ六ルル少くうで・てグ金にく、゙約実

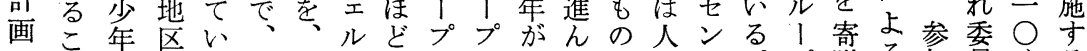

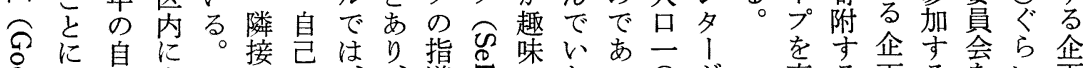

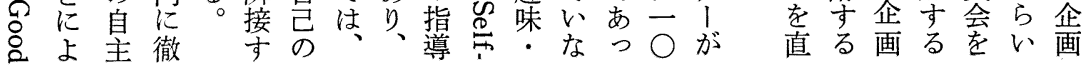

ををテヴこ導現ろもるすマ助のには選プ社て民年で

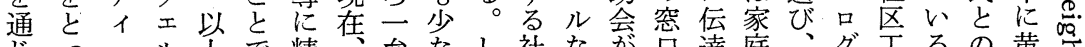

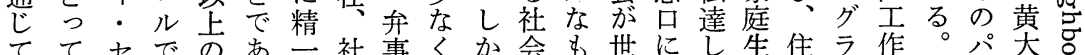

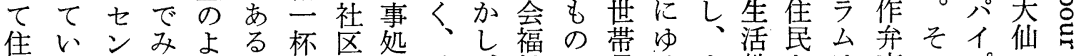
民る夕るう。王兄あ計、祉で員けま教とは事のプのも

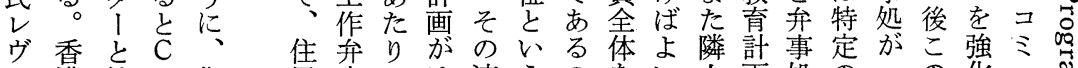
工港 社 $\mathrm{Y}$ 住

ル 清 区 O 民

に潔 エ がの

お運作住 福

万 動 弁民祉

さ事のに

れ家 処 活 関

、庭と動 す

こ生がをる

れ 活 各 組 政

ら 教 地織 府

の 育 区、の

活計で調し

動画分整く

をの担しみ

通実実、は

こ施施こ観

コこるを沜

ミのとコ地

工少ミ域

$=く 5$ こ

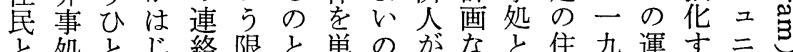
と処とじ絡限と単の咕なと住九運す 福どの 直悩のつはれ対とを祉政間ア三はこイ実 接み住た福た照卞指に府のパ年全と・施

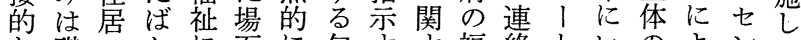
な職アかに面に包すす福絡トいのよンて パ員パり関で、括るる祉員をち方る夕、 イのと忍の $\mathrm{S}$ 的役問活に対は針住!る プ不卜い䯧組 W 割題動す象やと民货。 の足にうも織 D 住をでにるにくなの実こ 拡でしこつ化の民も困関と近こり、互験の 大あかと者のこのつつすい隣れ、助的計 にり普もに試の組ってるうのを観精に画 ま、是あ限み計織先い通も世は塘神はは で児しつらと画华にる知の話じでのじ、 手童ててれいはをみ場をでをめは育め一 がやい等主試た合同あょて秀成た九 ま青な目いこ婦みC 代るくい茂をも六 わ少い下るとをる $\mathrm{D}$ 彼階。みる坪目の九 ら年 Эのたが中フ O 5 の連る。南標で!

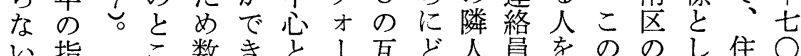


てれ力さ選約ままてわ考五衛とン地坊調るる $\mathrm{D}$ イ

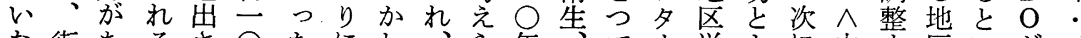

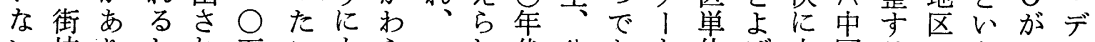
い坊りしれ万こもらコれ代公あを位ば中国るのう ○は地くる人と権れミてに安るもにれ国人機レ役 A口 し二域みもしに威てュいは関ヴ割Cプ か般社との現よをしニた政レ街顕と住によにェををメ し住会なの琵る志まテ。府ジ坊著つ民民るるな担通ン

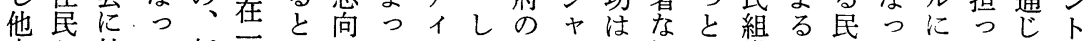
方加献て新、いして、加、加福な織民間てあてての ら身い加六わたいデしミなっ祉っで, 間組いつい住達

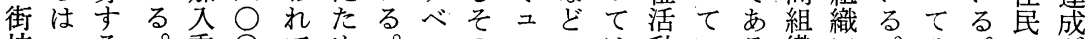

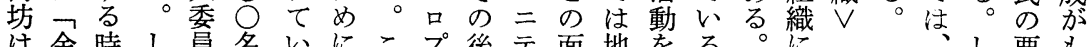

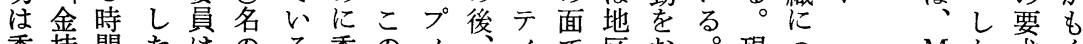

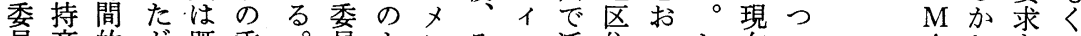
員商的が既委。員よンそ心活住こし在い

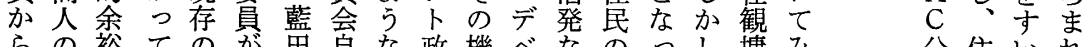
らの裕て、の思自な政機べなのっし塘み 分住いれ の集の、委お街体街策能口活自てそにる 区民公 て 寄まあ委員り、坊が坊のをプ動治いのはと委のげい 附りる員に、の二の推政メを組る活二、、員生、る によ自とよそ場般衰進府ン挍織の動四ま. 会活この よと営なるの合住退母やトこでははのずはがれで

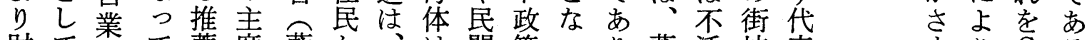
財て者て薦席藍か、澗策っり藍活坊表衣り亭る 政しないには田らそ $\mathrm{M}$ の推て、畐発が的密 $\mathrm{Y}$ 。 がかなるよ委の乘のA 機進お福街であな発な接 Oさ

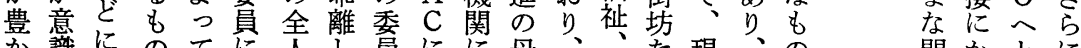

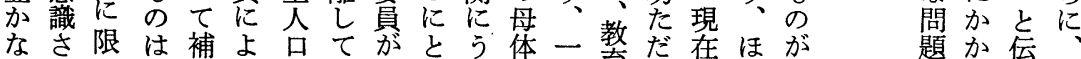

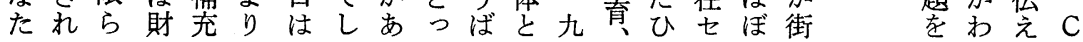

るに (1) 観

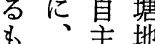
の 特運域 定営に のグあ 問ルる 題 プ鹪 心の組 をよ織 焦 点

と

し 組の

て 織 形

七的態

夕 背

景点

のを索

\& \& म

とたる

になど、組いる

織 個

さ人

れを

て対

以象
はででるがし営のあくI楽て学全、 区め 機はあ同、て守他り架古善い校香観内に 会なっ郷同いる、、らイ堂るが港塘で

五学、会族る。览小有中不竞楽ひ的に社地 五改。、命の。童童力国、東善となは会区 めな組あ有さ七群者人学華堂つ組こ的内 てお織る志らン益かに校言今、織のにの 々息。元に罢らよの院占ま少他大さ

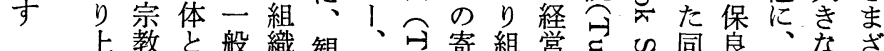
上教と般織観、点寄組営巨罗同良、なざ

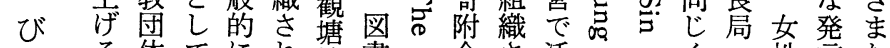

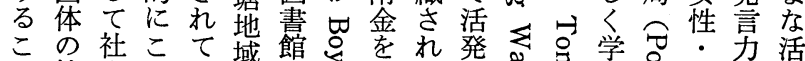

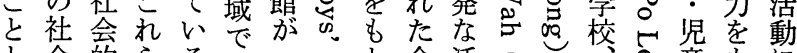
之会的 5 る

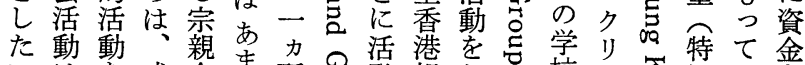

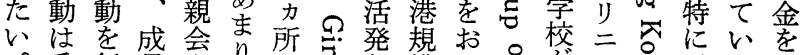

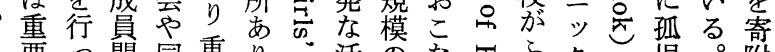
要っ間同重り○活のな写ふク、が呪。附

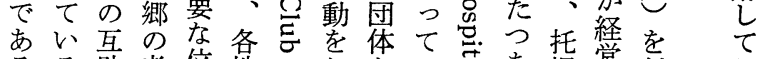

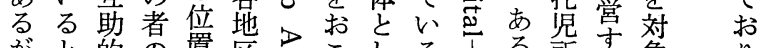

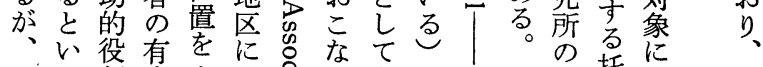

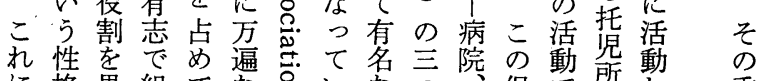

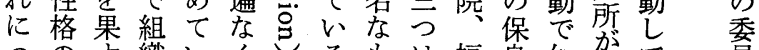

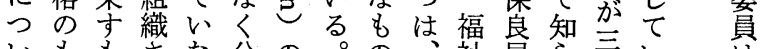

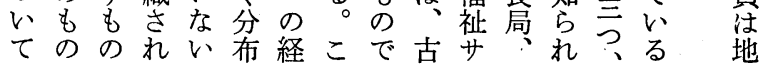


たに地織るの 三べな要のうの政生か第区の

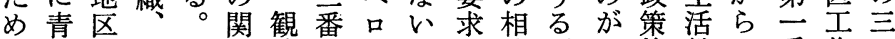

の少の調住係塘眘 プ。老談可ほ枠教み番作う扱 $\mathrm{M}$ た $\mathrm{S}$

活年レ整民は地のメ観政に能との㕕る自弁に㧤 A 分 W

動対ヴしの、域 $\mathrm{M} ン$ 啹府応性んも計との事わう C 野 D

を策ェて福政の A トににじをどと画、形処けとののの

組のルい祉府コC の市充適すでで実こ態おるすす問連

織分にるに機ミと推っ分切っあの施のをょこるう題絡

野あが関関ユい進てになてる青の二とびともにだ員

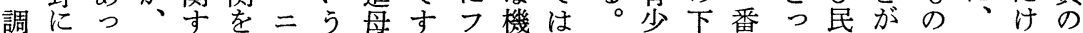

整留てこる中テこ体べィ関い二年部目て間で。すをよ

しまはれ活心イととて、のる番の末のいのき扱う

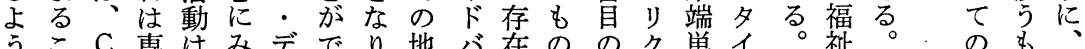

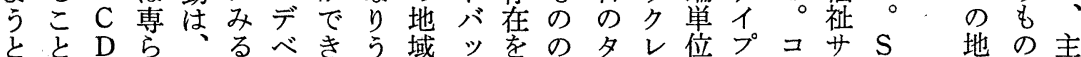

しな $\mathrm{O}$ 青観と口るる住ク教、イ、 I と ミミ I W 域、婦

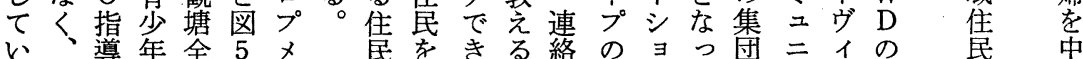

る広下対体のンの基るに員組ンてはテスコ

範・の策でよト

コな $\mathrm{M}$ にはうを

ミ生 $\mathrm{A}$ 力 $\mathrm{S}$ に推

二 活 $\mathrm{C}$ 点 $\mathrm{W}$ ま進

三去分架 $\mathrm{D}$ 市

1諸委かのるい

- 問筫れ $\mathrm{C} こ る$

デ題会て Y と主

ベ改会いO がな

口善、るがで機

プの単。組き関

主礎だ留は織活い政イ機ミ

要亡け年問は動る府・関二

組守のる題よにがのデの二

織る仕のをり力、香 べ活テ

はコ組でか広点そ港口動1

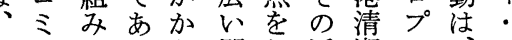

目ユにつえ問お活潔メ、セ

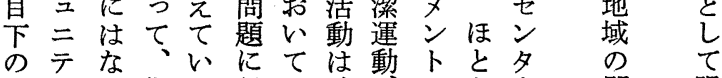

とィっ住る 対い政穴ん問限

ろ

委ひ営合し用メ 会つおそかるト のは、のし自の 委、て性な助 要 員そ、格が意之 はれ中そら、識も が央の、市

す財政も $M$ 高る

で政 府の $\mathrm{A}$ 揚 ベ に的官の $\mathrm{C}$ を み竜更な分ま $\mathrm{M}$

て付にか分さ $\mathrm{A}$

き訬に委にC

たをるふ委要分

表も指た罢請区

5 つ導つ会さ委

て性のをれ䆩

表いの售て会

6 な強宿民心会

か、以加のる

らとこあ代。地

わでとる議域

かあで。機の

るるあひ関資

う $\mathrm{M}$ りととと し 源

に $\mathrm{A}$ まて 有

Cたそみ 効

半分他のた に

図 5 観㭛地域のコミュニティ・デベロプメント推進諸機関

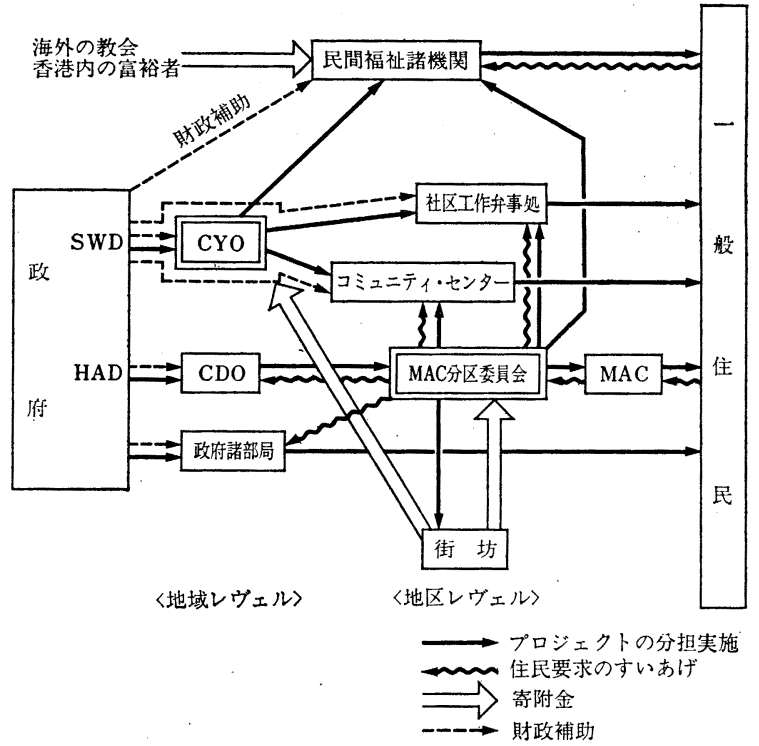

数区の運場活 
で定祉生善民附画動助にれとこしでカ いくらばとら以

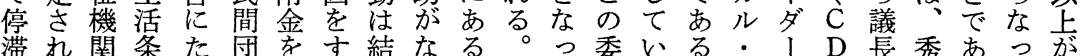
してを件よ体募る局く $\mathrm{M}$ さて買るがリシ $\mathrm{O}$ に茂って

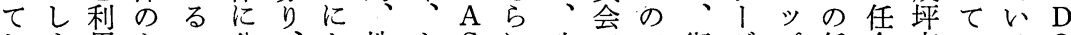
しま用あこ分、と地まCに政でで街ダプ任命南住る $\mathrm{O}$ まっすらの担まど区た分、策はは坊、を命さ分卞が任 ってるゆよ遂たまと独区政決、な委たとにれ区に、命 てい形るう行、り、ヴ自委府定政く員ちつよた委よその いるで分なさ海、エの員部が府地をはてり学員りこ委 るのの野しせ外そル財会局な官区別学い分校会避で員 とで金にくる。のので源に間さ吏内と校る区長で巽りな

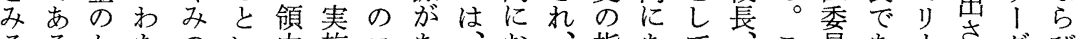

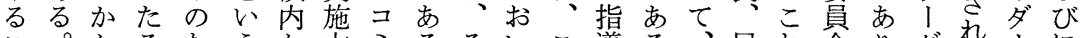
こ。かる.なうか方ミるそいこ導る、民れ会り名れ、に れ

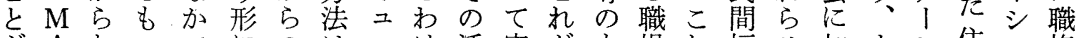
がAなのでにのは二け活実がも場れ福り加まシ住ッ権 でCいにのな寄、テで動行住とにら祉、わたッ氐プ上 きのリはそつ附街ィもの権民に通の機ダつ藍プ労をの

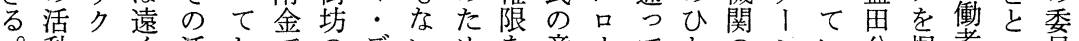
。動レく活しでのデいめを意！てとのシい分握者っ員 こは1及動ま活よべ。のも向カいび主ッる区っのてと の、シば範う動う口し財たをルると任プ街委て代いし よこヨず囲。しなプた源な反・のは坊員い表るて うのン、は富て富メがとい映りがそ街との会るでのの なし活専、裕い裕ンっし C し! 普の坊っ委ののは政 制く動ら地者る者トてて D だ通地のて員場はなこ府 度み分既域加地活、の O と / で区委いた合 C 的の野存社ら区ら動そ政指みがあに員るちは D。ひ吏

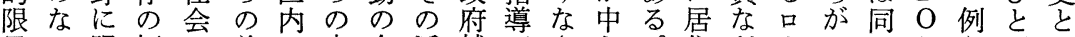
界か限福の慈の寄企活補下さ心。住ど、リじかえびか

も実関港る現わ活うどテレをのルポしにるるゆのを 非は係吕。行れ動にここイヴ中のでリてよと以く創乗

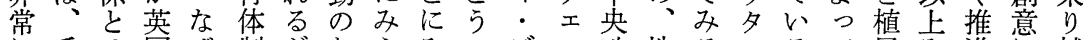
に香は国ぜ制がなえみいデル政地るンるて艮み進に越 大港決のこの、かる出つべで府域と香。住地て母よえ きのし植のなそに。せた口のの住、港そ民支き体るる

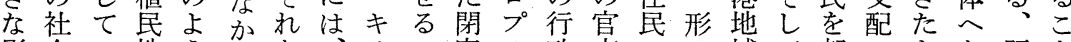
影会い地うでと师塞メ政更のの域て部のよと既と 響的えなのて政スで的ン主が代うに、分大う脱存が 桨まし消最反府卜あと体統議えとそ的枠に皮ので 与況いか極大娶政に教乃ももに制機でじのにの、年型き えに。も的限府対系うい充自す関は込領政も香るにな てば新政なの運しのかえ分主るに地め士治と港ことい い加界治運社動 ラ民。るな的とあ方ら構のにのとら限 るりの的動社にジ間現現効ないっ分れ成しあ政はわり とでリにし会つカ福在行果財うて権てのくり治でれ $\mathrm{M}$ 考な卜特か齿なル祉の体を源しは化い特み、、のきなA えくス殊み義がな団と制期がく、をる殊に英しないC ら、がならとる姿体この待なみ住推のさ参国くい新分

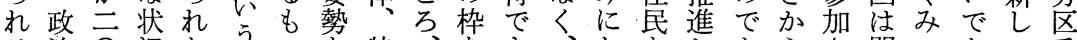
る治 ○況な うのを特、をき、なをしあらさ間のあい委 。的年のい要ともに確乗なこっ部てる、せ接特ろ形員 二、後なの求いつ力定りくのて分い。夥、統幑うで会 ○社にかかのうもり的越なない的るまし強治は、。 年会切にに性よのリなえつかるによたい力方、活 後意れあつ格りがッ方るてで。参う、人に式香動地 に識るるいのはあク向方、のし加に地口こを港を域 はのとこてもむる系は向るるコかさみ域がれと全形住 中状いとはのし、機な性。ミもせえレメをる体成民

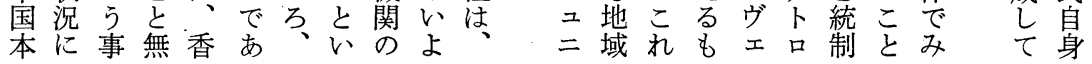




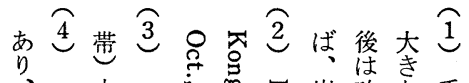

支九中、它:要出確な香

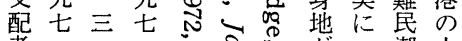

者年・年导守香乷潮人

イ゙の二の方怘港公流は

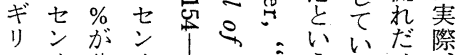

スサ公サ

人不共不

はに隹に

ずれにれ

かば入ば

- 香兄香

七港て港

し人化

加吕。全

いの 世

な九带

分 分

ま三酉

た \% 六

中中 六

国国学

人余

\section{क}

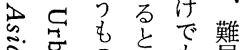

总

气全わ㐭染

ミ美机にに

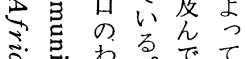

怘热ずでて

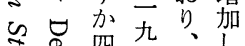

ミ怘四吉現た

空 戛年在部

○总にの告七年压

○るきざ間倒

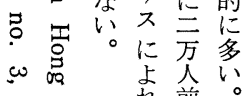

れ前
いのコかか住してたし士 部三附期な強はな詩なる自な香 で二記待いく、いの分い港 あテ孞し支政要で達だの るイ本隠と配治因はのろ解 。調さいさ的とな生う放 香デ.査れうれなしい活とを 港べはて香て関てだはい要 で口、以港い心作ろどう求 御プトる住るよ用らう莫し 教メヨよ民寻よりしかな然て 示ンタうのうはて。るとく をト財にこにむいそかしる 頂し団思とみしるしとたで 、代のえばえろのてい期あ た俵助てのる経でこう待ろ 多表成な背が済はの問をう 東にら後、的な意題、し

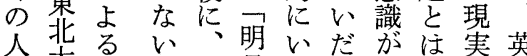
々学自。旦加、別に国 に学開 深佐発年こ儲加政、典々 心々途後之忖。府一がの 謝杰卡はる確運般引時 意徹国香だ加軼住掦 は 孝郎の港れとにに民出 表教都、のにい香いはたて し授市変もう港たもとゆ た.揥斾

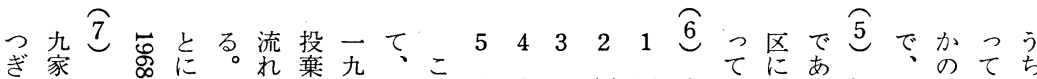
の族例亦彼込場五政杂导与芯当心集る観ほほ心の

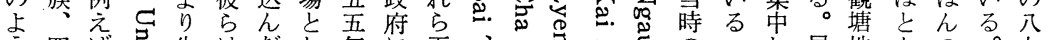

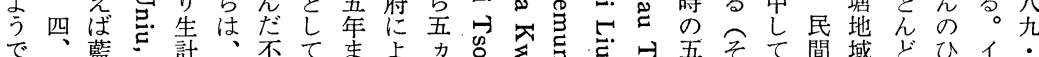

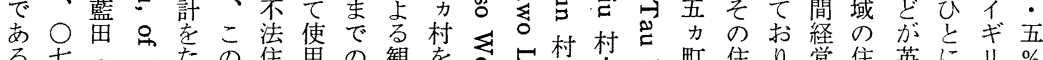

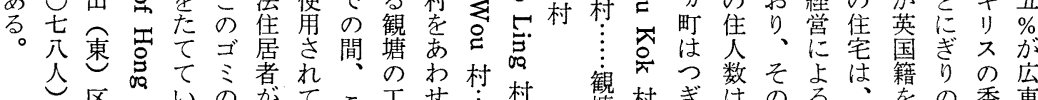

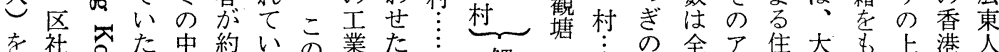

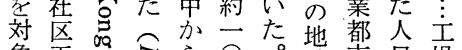

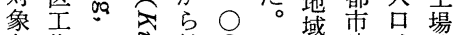
々作? 号鉄 ○こ域建は建 し 弁舟ミくのの設約築

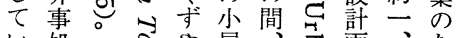
心処。る屋至画、た るの のゴをゴすが○め が場 $\because$ 厶うミ心は○解

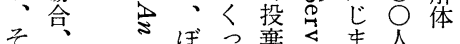

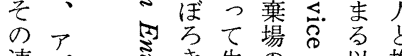
連分さき生のも以推 絡 豆㧈活近寻前定 員卜ミ在し边染のさ

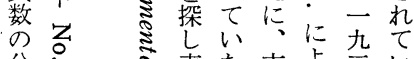
分。ミ壳た市上㤂い 布曰的亡街て言る。 芯分李心地て年。

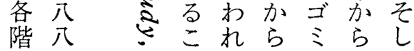

鯉凹

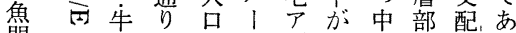
門開頭でのトハ政国ポはり 茶発角あ主数贞府官不典残

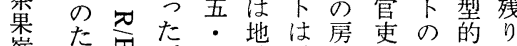

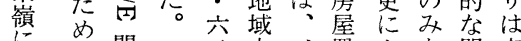
に解開 \%内心署よを間客

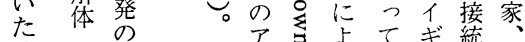
只運 リ治鶴 1尺て営スで佬

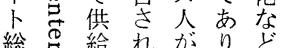
数、答て占、の の牛机いめ政少 頭てるて府数 五角い。い機民 \% る る 構 族 と工も だのと な場のけなな 


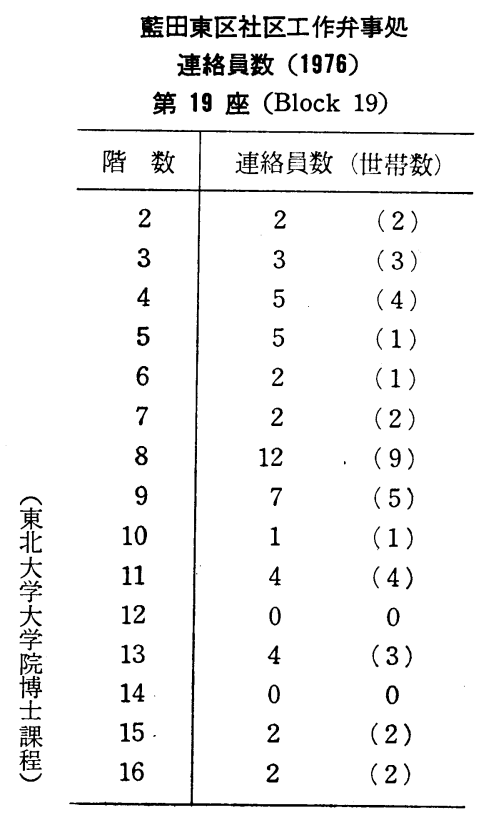




\title{
Life Cycle of Rural Families and Cooperative Groups
}

\author{
Naoto Sugioka \\ Hokkaido University
}

Recently, regional organization of farms takes an important place in both agricultural policy and actual farmings.

The present paper attemps to account for the interrelations between family life cycle and rural cooperative groups. The basic component of the groups should be regarded as a family rather than a farmer himself.

It seems worth while to inquiry how the developmental process of rural families relates with the dynamics of the rural cooperative groups.

Two groups are here concerned; one is 'Motosatsunai Nojyo' as a productive cooperatives, the other 'Motosatsunai Kikai Riyo Kumiai' as a group which is organized to use common agricultural machines.

In this study is adopted family life cycle approach based on R.H. Rogers' 24 categories; it is a longtudinal study of the rural change for 15 years from 1960 to 1975 . When we forcus on the development of the cooperative groups, the homogeneity of life cycle of the group members is connected with persistence and integration of productive groups. Additionally, the principle of group formation is not dependent on kinship relations as it used to be.

\section{Social Problems and Community Development in Urban Settings in Hong Kong}

\section{Hiroaki Konno}

\section{Tohoku University}

Since 1950 Hong Kong has been developing industries greatly with its rapid increase in population, mainly caused by refugees. More than 4 milions people are living in Hong Kong, 88 per cent of them are in the Metropolitan Hong Kong. Most of these people living in narrow urban area are poor workers. These people are facing various social problems caused by its overpopulated situation. In order to solve these problems, in 1968 the Hong Kong 
Government launched the urban community development program by establishing the City District Office Scheme. The Government now adopts the decentralization of power, and intends to pursue the grass-root community development. However, it seems that they can not get an expected result so far.

In this article, I examined the reason why satisfying achievements in urban community development in Hong Kong have not attained, from the view point of political scheme of society, especially that in the district level. These examination are based on the data from our research held in Kwun Tong, Hong Kong, in the summer of 1976.

Firstly, social problems which the people in Hong Kong are now facing to are examined. They cover all of the living phases; problems such as housing, water shortage, unemployment, trafic, education, crimes, social welfare, medical care and pollution.

Secondly, community development in a district level is intensively examined by picking up the Kwun Tong case, especially from the aspect of local organizations involved. The Area Committee in Mutual Aid Committee Scheme under the direction of the City District Office is identified as the most important local organization for a community develpment in a district. This MACArea Committee is a representative organization of the residents and a basic unit for the urban community development. However, the Hong Kong Government controls strongly this Committee through Government officers. Moreover, the Area Committee does not have its own source of revenue. The source of revenue is the donation from the local leaders. Thus there is a discrepancy between the administrative body and the local residents. The urban community development is stagnating under these political scheme of society.

Also the fact that the lease of the New Territories will be terminated after 20 years from now has produced a negative attitude toward the reform.

\section{The Possibility of the Approach of Social Pathology from Social Formation}

- Examination of the Concept of Anomie -

\section{Shigenobu Yonekawa Bunkyo Univ. Women's Junior College}

An approach of social pathology from social formation is possible through the examination of the concept of anomie. The contradiction between desire 